\title{
Magnetic resonance imaging changes in pediatric temporomandibular joint: literature review
}

\author{
- Gonzalo André Montesinos Department of Stomatology, School of Dentistry, University of São Paulo, São Paulo, \\ Brazil - Rosa Cristina Peinado Agudo Department of Stomatology, School of Dentistry, University of São Paulo, São Paulo, \\ Brazil • André Camilo de Oliveira Department of Stomatology, School of Dentistry, University of São Paulo, São Paulo, Brazil \\ - André Antonio James School of Dentistry, University of São Paulo, São Paulo, Brazil • Jefferson Xavier Oliveira Department \\ of Stomatology, School of Dentistry, University of São Paulo, São Paulo, Brazil • Juliane Pirágine Araujo Department of \\ Stomatology, School of Dentistry, University of São Paulo, São Paulo, Brazil
}

ABSTRACT | Magnetic resonance imaging is effective to diagnose some diseases that affect the temporomandibular joint (TMJ) of children. The images allow the detection of early stages of juvenile idiopathic arthritis, cases of joint ankylosis and is currently considered the most reliable exam for an objective and noninvasive assessment of intracapsular soft tissues. The objective of this literature review was to assess some of the temporomandibular joint changes in children using magnetic resonance imaging (MRI). The assessment of TMJs of children performed through MRI make the diagnosis more accurate and objective. Detecting alterations during the early stages of juvenile idiopathic arthritis using 3T MRI devices is possible utilizing contrast tools, which as a result, provides better prognosis and treatment.

DESCRIPTORS | Temporomandibular Joint; Child; Magnetic Resonance Imaging.

RESUMO || Alterações na ressonância magnética em articulações temporomandibulares de crianças: revisão de literatura • A ressonância magnética é eficaz para diagnosticar algumas doenças que afetam a articulação temporomandibular (ATM) de crianças. As imagens permitem a detecção dos estágios iniciais da artrite idiopática juvenil, casos de anquilose articular, sendo atualmente considerado o exame mais confiável para avaliação objetiva e não invasiva de tecidos moles intracapsulares. O objetivo desta revisão da literatura foi avaliar algumas das alterações da ATM em crianças por meio de imagens de ressonância magnética (IRM). A avaliação das ATM de crianças por meio de IRM torna o diagnóstico mais preciso e objetivo. A detecção de alterações durante os estágios iniciais da artrite idiopática juvenil usando aparelhos de RM de $3 \mathrm{~T}$ (Tesla) é possível pela utilização de ferramentas de contraste, que, como resultado, proporcionam melhor prognóstico e tratamento.

DESCRITORES | Articulação Temporomandibular; Criança; Imagem por Ressonância Magnética.

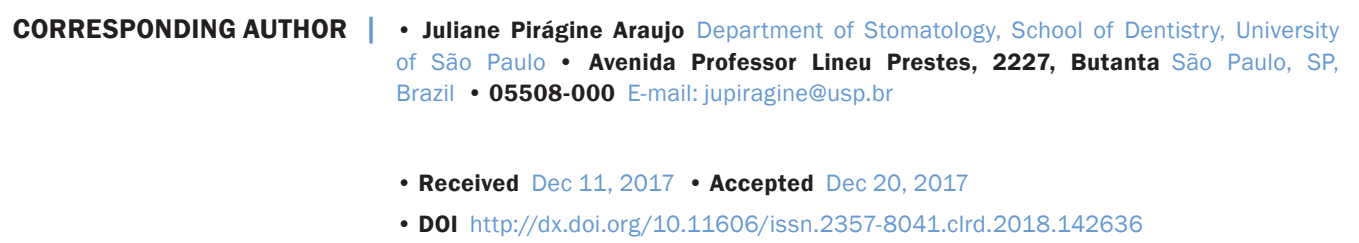




\section{INTRODUCTION}

The temporomandibular joint (TMJ) is a complex joint composed of a conjunction of soft and bony tissue structures. The squamous portion of the temporal bone (represented by the articular tubercle and the fossa of the mandible) and the condyle comprises the bony components. The soft tissues are represented by the articular disc, dense fibrous tissue, articular capsule, intrinsic and extrinsic ligaments, as well as articular cartilage. ${ }^{1}$ Temporomandibular disorders (TMD) present a multifactorial etiology, which may include muscular disorders and disorders of the TMJ itself. Pain and clicking are the most common signs and symptoms reported by patients. ${ }^{2}$

Magnetic resonance imaging (MRI) is considered the golden standard for the diagnosis of changes in the structure of the TMJ,3,4 due to the possibility of producing images in different planes, dynamic studies, and by not requiring ionizing radiation. ${ }^{5,6}$ Currently, MRI is the most reliable examination for an objective and noninvasive assessment of the intracapsular soft tissue. Conventional radiographs and computed tomography present limitations for soft tissue evaluation, and arthroscopy is an invasive procedure. 7 Devices with a field energy of 1.5 Tesla ( $\mathrm{T}$ ) or $3 \mathrm{~T}$ can be used, with the characteristics of each fiber determining the images generated. Signalrich images appear clear (hypersignal) and a poor signal image appears dark (hyposignal). ${ }^{1}$

The objective of this study was to perform a literature review on the evaluation and diagnosis of the changes that can affect the TMJ of children through MRI images.

\section{DISCUSSION}

The main imaging examinations used to evaluate the TMJ are panoramic radiography, ultrasonography, computed tomography (CT), cone beam computed tomography, and MRI. Each method has advantages and limitations, thus, the radiologist must know their correct indications. Panoramic radiographs should not be used to assess the condyle and joint fossa due to the overlapping of structures. ${ }^{6}$ Ultrasonography represents a convenient and noninvasive modality without exposure to ionizing radiation. The limitation of this examination is the lack of view of osseous and dense soft tissue structures, resulting in the visualization of the superficial (lateral) region of the TMJ. Ultrasound-guided procedures are excellent to guide the intra-articular injection of anti-inflammatory drugs. ${ }^{8}$ The articular disc cannot be observed through conventional radiographs or $\mathrm{CT}$, which provide information about traumas, infections and congenital anomalies of the TMJ. ${ }^{9}$ CT allows the detection of fractures, small erosions and morphological alterations of the bone tissue. Soft tissue structures, including the articular disc, can be observed but are difficult to identify in the presence of joint effusion or synovial thickening. ${ }^{8}$ Based on its high sensitivity and specificity, MRI became the modality of choice for the early diagnosis of TMJ damage. MRI is the only technique that allows the detection of bone marrow edema ${ }^{6}$ and also an excellent evaluation of the articular disc and its supporting structures, joint fluid, synovial thickening, and bone changes (edema, erosion and morphology). ${ }^{8}$ MRI effectively assists in various TMJ treatments and is important in monitoring structural changes that may occur in the TMJ, thus, allowing for adjustments in the clinical therapy. ${ }^{10}$ The disadvantages of MRI include long periods of patient scanning, device noise, and discomfort due to need of maintaining the mouth open for the sequences to acquire the images. ${ }^{8}$

The most common observed image findings in the MRI of children are synovitis and effusion. If there is evolution in the condition, subchondral cysts, erosions, a decrease in the volume condyle process and anomalies on the morphology of the articular disc may be observed.4,6,11 Moe et al., performed 
a study with imaging findings of the TMJ of 87 healthy children. The tests were performed using 1.5 and $3 \mathrm{~T}$ devices, standardized protocols, with or without contrast (Table 1). The following structures were observed with hypersignal: medullary bone of the mandibular condyle in $70 \%$ of the cases (Fig. 1), articular fossa cortex in $64 \%$, and condyle cortex in $56 \%$ (Fig. 2). The authors claim that the image findings of healthy children should present clinical correlation for correct diagnosis. ${ }^{4}$

Table 1 | Imaging protocol used in some studies.

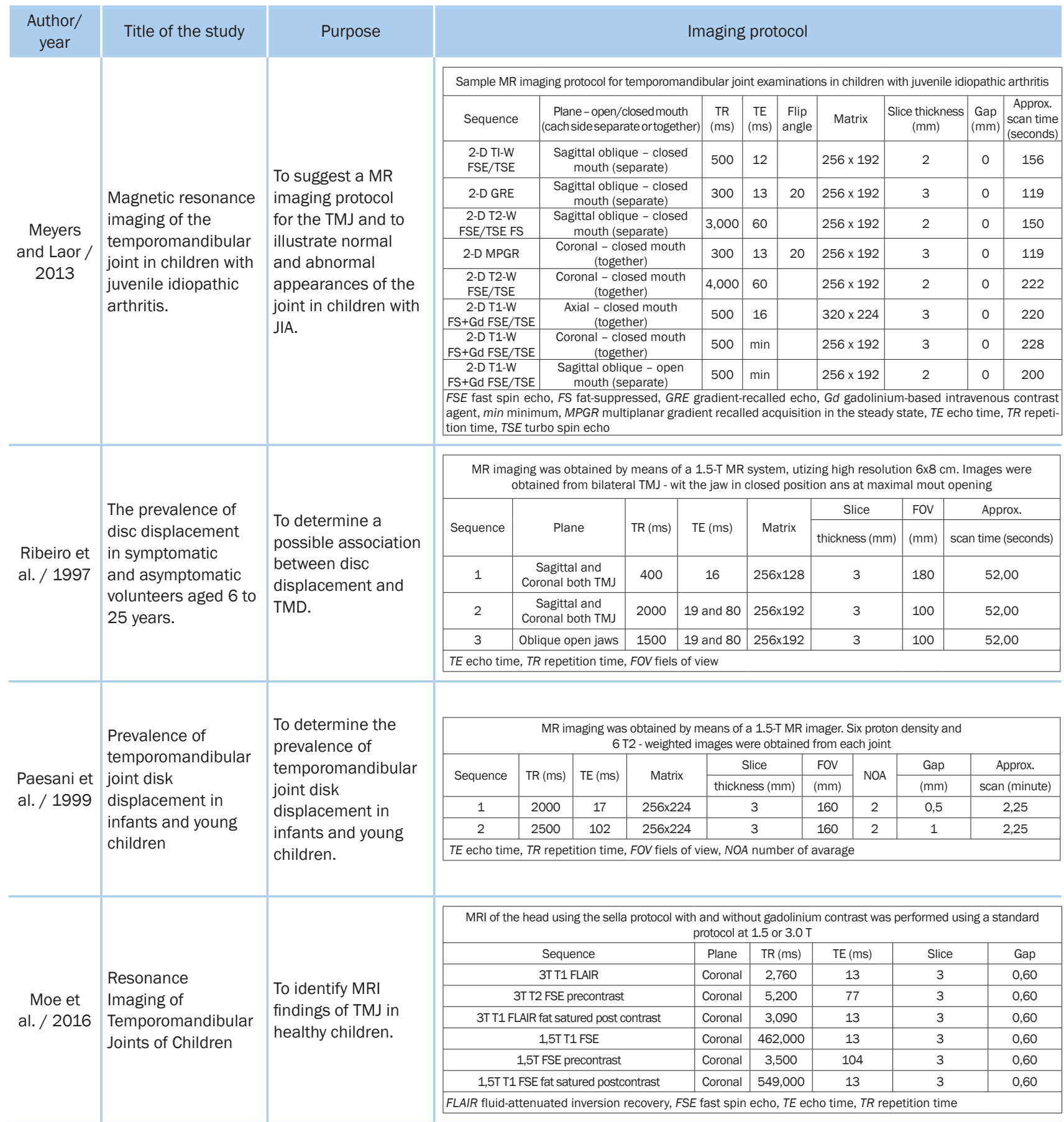


Table 1 | Continuation

\begin{tabular}{|c|c|c|c|c|c|c|c|c|c|c|c|c|c|c|}
\hline $\begin{array}{l}\text { Author/ } \\
\text { year }\end{array}$ & Title of the study & Purpose & & & & & nagin & g prot & tocol & & & & & \\
\hline \multirow{11}{*}{$\begin{array}{l}\text { Meyers and } \\
\text { Laor/2013 }\end{array}$} & \multirow{11}{*}{$\begin{array}{l}\text { Magnetic resonance } \\
\text { imaging of the } \\
\text { temporomandibular } \\
\text { joint in children with } \\
\text { juvenile idiopathic } \\
\text { arthritis }\end{array}$} & \multirow{11}{*}{$\begin{array}{l}\text { The purpose of this } \\
\text { review is to suggest } \\
\text { an MR imaging } \\
\text { protocol for the } \\
\text { temporomandibular } \\
\text { joint and to } \\
\text { illustrate normal } \\
\text { and abnormal } \\
\text { appearances of the } \\
\text { joint in children with } \\
\text { JIA. }\end{array}$} & \multicolumn{12}{|c|}{ Sample MR imaging protocol for tempomandibular joint examinations in children with juvenile idipathic arthritis } \\
\hline & & & Sequence & \multicolumn{3}{|c|}{$\begin{array}{c}\text { Plane-open/closed mouth } \\
\text { (cachsideseparate ortogether) }\end{array}$} & $\begin{array}{c}\text { TR } \\
(\mathrm{ms})\end{array}$ & $\begin{array}{c}\mathrm{TE} \\
(\mathrm{ms})\end{array}$ & $\begin{array}{c}\text { Flip } \\
\text { angle }\end{array}$ & Matrix & \multicolumn{2}{|c|}{$\begin{array}{c}\text { Slice thickness } \\
(\mathrm{mm})\end{array}$} & $\begin{array}{c}\text { Gap } \\
(\mathrm{mm})\end{array}$ & \begin{tabular}{|c|} 
Approx. \\
scan time \\
(seconds)
\end{tabular} \\
\hline & & & $\begin{array}{l}\text { 2-D TI-W } \\
\text { FSE/TSE }\end{array}$ & \multicolumn{3}{|c|}{$\begin{array}{c}\text { Sagittal oblique - closed } \\
\text { mouth (separate) }\end{array}$} & 500 & 12 & & $256 \times 192$ & \multicolumn{2}{|l|}{2} & 0 & 156 \\
\hline & & & 2-D GRE & \multicolumn{3}{|c|}{$\begin{array}{l}\text { Sagittal oblique - closed } \\
\text { mouth (separate) }\end{array}$} & 300 & 13 & 20 & $256 \times 192$ & \multicolumn{2}{|l|}{3} & 0 & 119 \\
\hline & & & $\begin{array}{l}\text { 2-D T2-W } \\
\text { FSE/TSE FS }\end{array}$ & \multicolumn{3}{|c|}{$\begin{array}{c}\text { Sagittal oblique - closed } \\
\text { mouth (separate) }\end{array}$} & 3,000 & 60 & & $256 \times 192$ & \multicolumn{2}{|l|}{2} & 0 & 150 \\
\hline & & & 2-D MPGR & \multicolumn{3}{|c|}{$\begin{array}{l}\text { Coronal - closed mouth } \\
\text { (together) }\end{array}$} & 300 & 13 & 20 & $256 \times 192$ & \multicolumn{2}{|l|}{3} & 0 & 119 \\
\hline & & & $\begin{array}{l}\text { 2-D T2-W } \\
\text { FSE/TSE }\end{array}$ & \multicolumn{3}{|c|}{$\begin{array}{c}\text { Coronal - closed mouth } \\
\text { (together) }\end{array}$} & 4,000 & 60 & & $256 \times 192$ & \multicolumn{2}{|l|}{2} & 0 & 222 \\
\hline & & & \begin{tabular}{|c|} 
2-D T1-W \\
FS+Gd FSE/TSE \\
\end{tabular} & \multicolumn{3}{|c|}{$\begin{array}{l}\text { Axial - closed mouth } \\
\text { (together) }\end{array}$} & 500 & 16 & & $320 \times 224$ & \multicolumn{2}{|l|}{3} & 0 & 220 \\
\hline & & & \begin{tabular}{|c|} 
2-D T1-W \\
FS+Gd FSE/TSE \\
\end{tabular} & \multicolumn{3}{|c|}{$\begin{array}{c}\text { Coronal - closed mouth } \\
\text { (together) }\end{array}$} & 500 & $\min$ & & $256 \times 192$ & \multicolumn{2}{|l|}{3} & 0 & 228 \\
\hline & & & \begin{tabular}{|c|} 
2-D T1-W \\
FS+Gd FSE/TSE
\end{tabular} & \multicolumn{3}{|c|}{$\begin{array}{l}\text { Sagittal oblique - open } \\
\text { mouth (separate) }\end{array}$} & 500 & $\min$ & & $256 \times 192$ & \multicolumn{2}{|l|}{2} & 0 & 200 \\
\hline & & & \multicolumn{12}{|c|}{$\begin{array}{l}\text { FSE fast spin echo, FS fat-suppressed, GRE gradient-recalled echo, Gd gadolinium-based intravenous contrast } \\
\text { agent, min minimum, MPGR multiplanar gradient recalled acquisition in the steady state, TE echo time, TR repeti- } \\
\text { tion time, TSE turbo spin echo }\end{array}$} \\
\hline \multirow{8}{*}{$\begin{array}{c}\text { Navallas } \\
\text { et al./2017 }\end{array}$} & \multirow{8}{*}{$\begin{array}{l}\text { MR Imaging of the } \\
\text { Temporomandibular } \\
\text { Joint in Juvenile } \\
\text { Idiopathic Arthritis: } \\
\text { Technique and } \\
\text { Findings }\end{array}$} & \multirow{8}{*}{$\begin{array}{l}\text { To provide a } \\
\text { comprehensive } \\
\text { review and update } \\
\text { of the most } \\
\text { relevant aspects } \\
\text { of assessment for } \\
\text { JIA, with emphasis } \\
\text { on the MR imaging } \\
\text { findings. }\end{array}$} & \multicolumn{10}{|c|}{ MR Imaging protocol } & & \\
\hline & & & Sequence & $\begin{array}{l}\text { Contrast } \\
\text { Material }\end{array}$ & $\begin{array}{l}\text { FOV } \\
(\mathrm{cm})\end{array}$ & \begin{tabular}{|c|} 
Section \\
Thickness \\
$(\mathrm{mm})$ \\
\end{tabular} & \multicolumn{2}{|c|}{ s $\begin{array}{c}\text { Intersection } \\
\text { Gap }\end{array}$} & $\begin{array}{c}\text { TR } \\
(\mathrm{msec})\end{array}$ & $\left(\begin{array}{c}\mathrm{TE} \\
(\mathrm{msec})\end{array}\right.$ & Frequency & Phase & e NSA & $\begin{array}{c}\text { Time } \\
(\text { min:sec })\end{array}$ \\
\hline & & & \begin{tabular}{|c|}
$\begin{array}{c}\text { Proton-density- } \\
\text { weighted } \\
\text { sagittal }\end{array}$ \\
\end{tabular} & Precontrast & 12 & 2 & & 0 & 1500 & 24 & 256 & 224 & 3 & 2:09 \\
\hline & & & \begin{tabular}{|c|}
$\begin{array}{c}\text { Fat -supressed } \\
\text { T2-weighted } \\
\text { sagittal }\end{array}$ \\
\end{tabular} & Precontrast & 12 & 2 & & 0 & 3000 & 85 & 256 & 224 & 3 & $2: 12$ \\
\hline & & & \begin{tabular}{|c|} 
T1-weighted \\
coronal
\end{tabular} & Precontrast & 15 & 2 & & 0 & 400 & MinFull & 256 & 224 & 1.5 & 4:03 \\
\hline & & & \begin{tabular}{|c|} 
Fat-suppressed \\
T1-weighted \\
axial
\end{tabular} & Postcontrast & 14 & 2 & & 0 & 375 & MinFull & 256 & 224 & 1.5 & $4: 15$ \\
\hline & & & \begin{tabular}{|c|} 
Fat-suppressed \\
T1-weighted \\
coronal \\
\end{tabular} & Postcontrast & 12 & 2 & & 0 & 500 & MinFull & 256 & 224 & 3 & $3: 49$ \\
\hline & & & & $F O V=$ field & W & $A=$ numbe & berof & nals & uired, 1 & $\mathrm{TE}=\mathrm{echo}$ & $\mathrm{e}, \mathrm{TR}=$ repe & etitionti & time. & \\
\hline
\end{tabular}

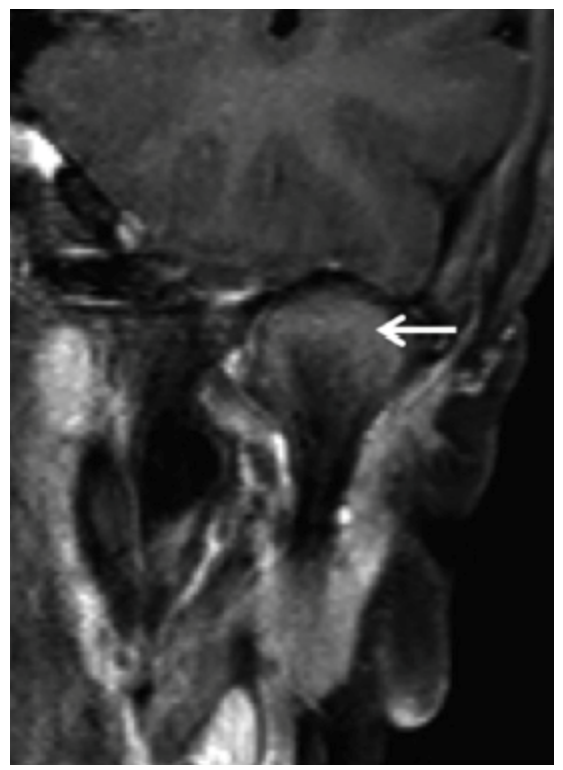

Figure 1 || Coronal T1 fat-saturated post-contrast image shows condylar enhancement (arrow). ${ }^{3}$

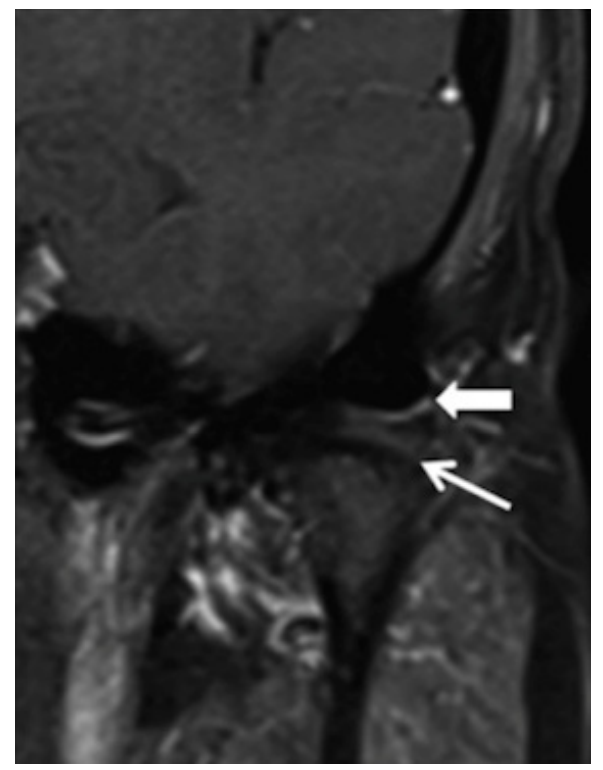

Figure 2 | Coronal T1 fat-saturated post-contrast (right) images of the left temporomandibular joint show glenoid synovial enhancement (thick arrow) and condylar margin synovial enhancement (thin arrow). ${ }^{3}$ 
Juvenile idiopathic arthritis (JIA) is an autoimmune disease that affects the joints, especially the TMJ of children, which may cause chronic synovial inflammation with a high risk of progressive joint destruction, leading to important functional alterations. JIA starts before the age of 16 , with a minimum duration of six weeks. MRI can detect the presence of osseous edema (Fig. 3), joint effusion (Fig. 4), bone erosion (Fig. 5), joint damage, and changes in the articular disc, which may correspond to the initial stage of the disease. ${ }^{6}$ Therefore, the use of T1-weighted images after administration of the contrast material gadolinium, is mandatory for the correct diagnosis. ${ }^{6} \mathrm{~A}$ T2weighted sequence with fat saturation provides the optimal assessment for joint fluid and edema within tissues. ${ }^{8}$ One study showed that when 3 T MRI devices were used with contrast, $87 \%$ of the children presented changes on the TMJ due to a disease, such as condylar erosion. This high percentage corresponds to the best condition of observing the articular disc and synovial changes.10 In another study, 11 patients (12 TMJs) were evaluated following the protocols with and without contrast in an $1.5 \mathrm{~T}$ device. The results showed that $71 \%$ of patients presented JIA and active synovitis (Fig. 6) in TMJs that were asymptomatic. Furthermore, $63 \%$ presented normal results in the physical examinations ${ }^{6}$, highlighting the importance of the early detection of these alterations, which will influence the treatment of these patients. ${ }^{12,13}$

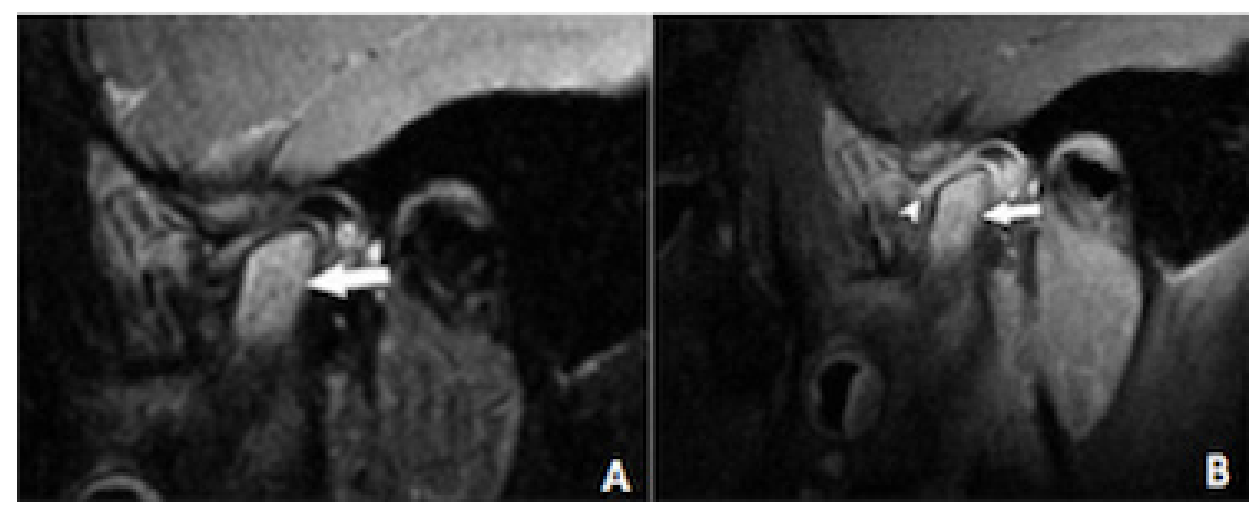

Figure 3 | A: Sagittal oblique T2-weighted fat-suppressed image shows an edema-like signal intensity within the mandibular condyle (arrow). B: Sagittal oblique T1-weighted contrast-enhanced fat-suppressed image shows diffuse enhancement of the mandibular condyle (arrow) associated with active synovitis (arrowhead). ${ }^{5}$

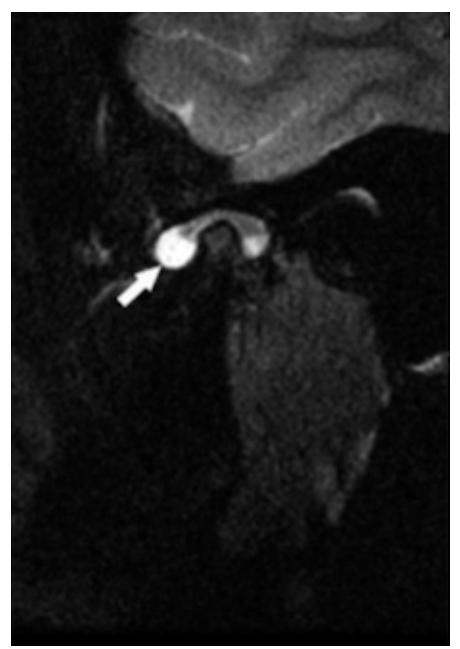

Figure 4 | Sagittal oblique T2-weighted fat-suppressed image shows joint fluid (arrow) that clearly delineates the shape of the disk between the upper and lower joint spaces. ${ }^{5}$ 
The articular disc is composed of a fibrocartilaginous tissue with a biconcave shape, it is divided into an anterior band, a posterior band and the intermediate zone which is located between the articular eminence and the condyle. The disc is seen as a hyposignal in T1-, T2- and $\mathrm{T}^{*}{ }^{*}$-weighted images. ${ }^{9}$ Studies with asymptomatic children and adolescents present a prevalence of cases of joint disc displacement, which were verified using MRI produced by $1.5 \mathrm{~T}$ devices. For $\mathrm{T} 1$, the images were observed in the sagittal and coronal sections of the condyles. The prevalence was of $6 \%$ in children with a mean age of 11 years and of $34 \%$ in adolescents with a mean age of 17 years. ${ }^{14,15}$ Another study using T2 sagittal sectioned images obtained from an $1.5 \mathrm{~T}$ device, showed that there is a minimum probability of joint disc displacement occurring in children younger than 5 years, due to the relatively flat morphology of the mandibular fossa and the small projection of the articular eminence (Fig. 7). Therefore, the authors believe that joint disc displacement may be an acquired anatomical condition, since the prevalence of this condition in adolescents is very similar to that of adults. ${ }^{16}$

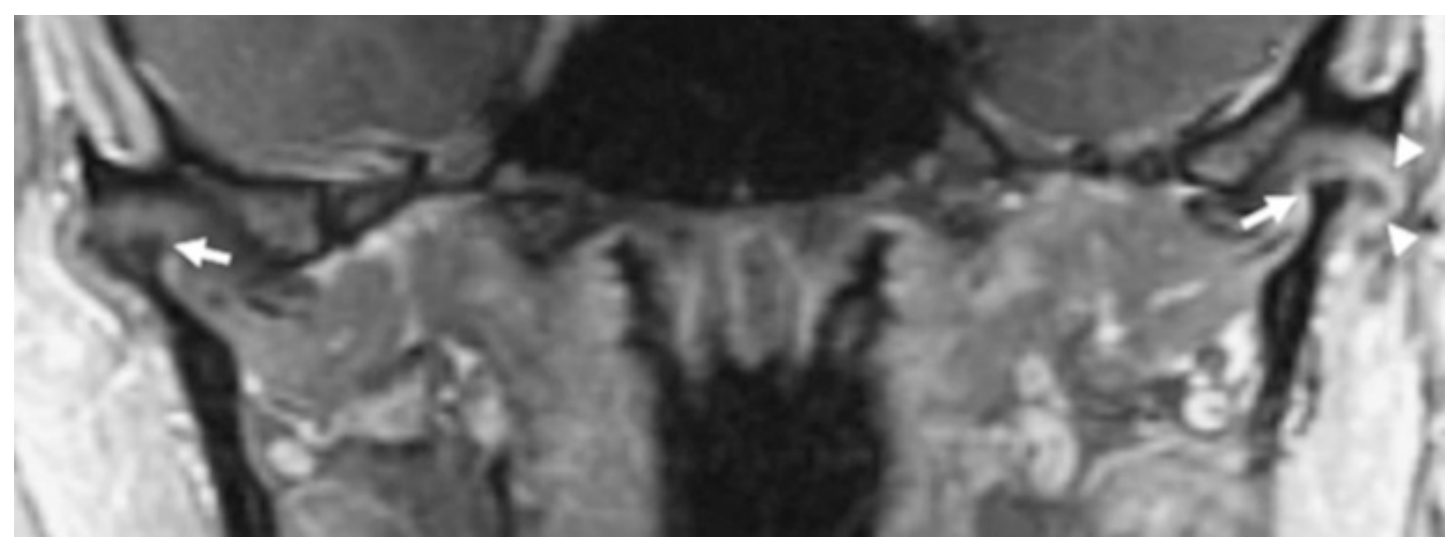

Figure 5 | Erosive deformity in the temporomandibular joint of a 16-year-old girl with JIA. Coronal T1-weighted contrastenhanced MR image shows extensive bilateral erosive changes of both mandibular condyles (arrows). Both discs are severely attenuated. There is left temporomandibular joint synovial thickening and enhancement (arrowheads). ${ }^{7}$

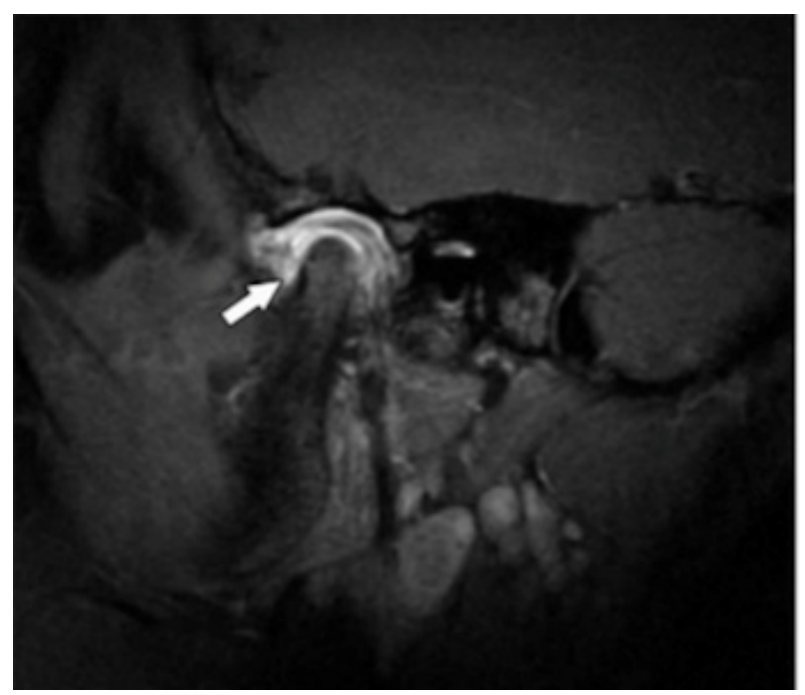

Figure 6 | Sagittal oblique T1-weighted contrast-enhanced fatsuppressed image show an active synovitis. ${ }^{5}$ 


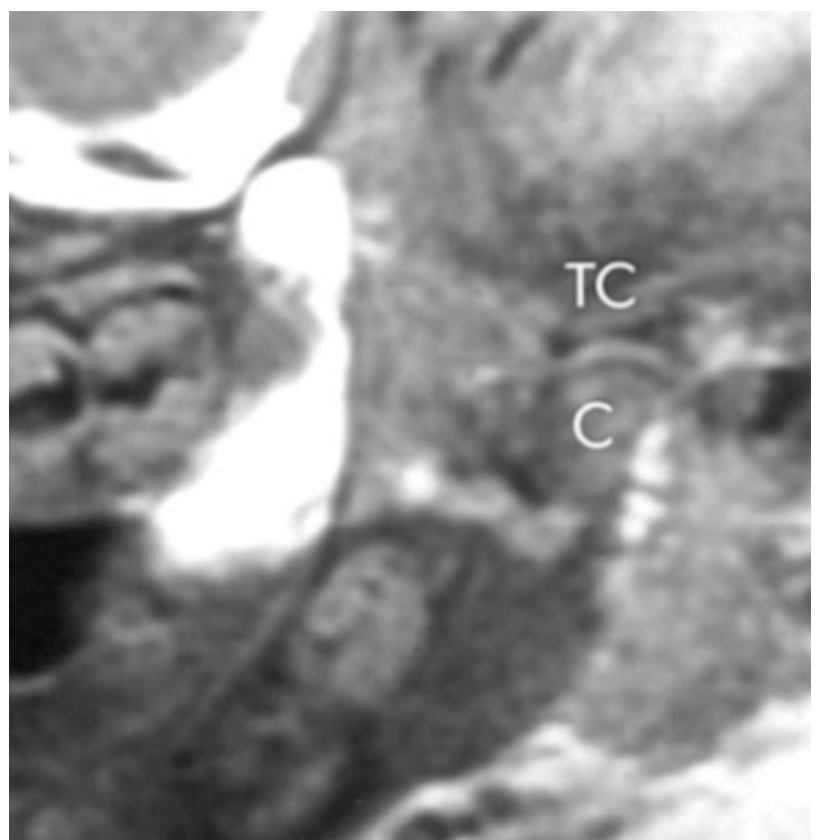

Figure 7 | 2-month-old baby with normal TMJ disk position above the condyle (C). Temporal joint component (TC) is flat, with little articular eminence..$^{13}$

TMJ ankylosis is a condition that may be associated with trauma (Fig. 8 and 9), local or systemic infections, untreated condyle fractures, congenital disorders or in some cases, it can be idiopathic. The clinical manifestation is a limitation of mouth opening, which can lead to the deformation of the mandible associated with facial asymmetry and occlusion problems. ${ }^{17,18}$ This change can be complete, in which the condyle of the residual mandible and the joint fossa are completely fused, or partial, in which it is possible the distinguish the condyle from the rest of the joint. For the correct diagnosis and elaboration of an adequate treatment plan, it is necessary to evaluate the condition of the articular disc (shape, dimension and position). MRI associated with CT images, which are used to study the anatomical structures of the TMJ and its respective bone alterations, is the best image exam that provides this data. ${ }^{19,9}$

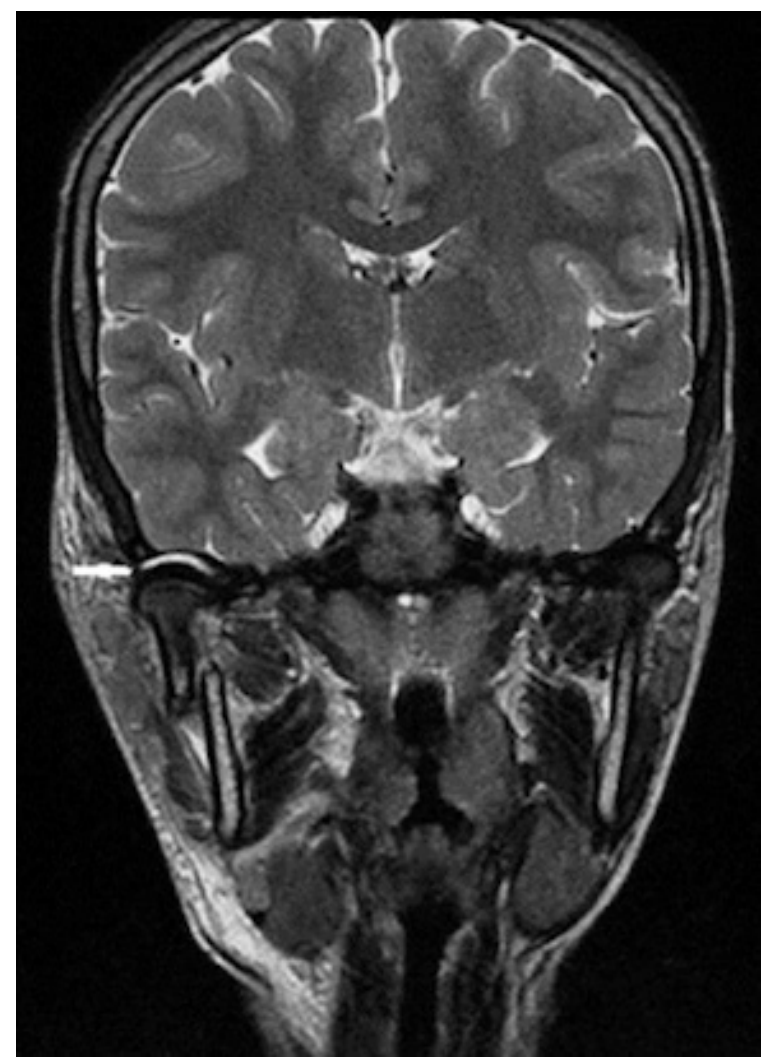

Figure 8 | Coronal magnetic resonance image of a 13-year-old child showing a right subcondylar fracture and a tear of the joint capsule (arrow). ${ }^{6}$

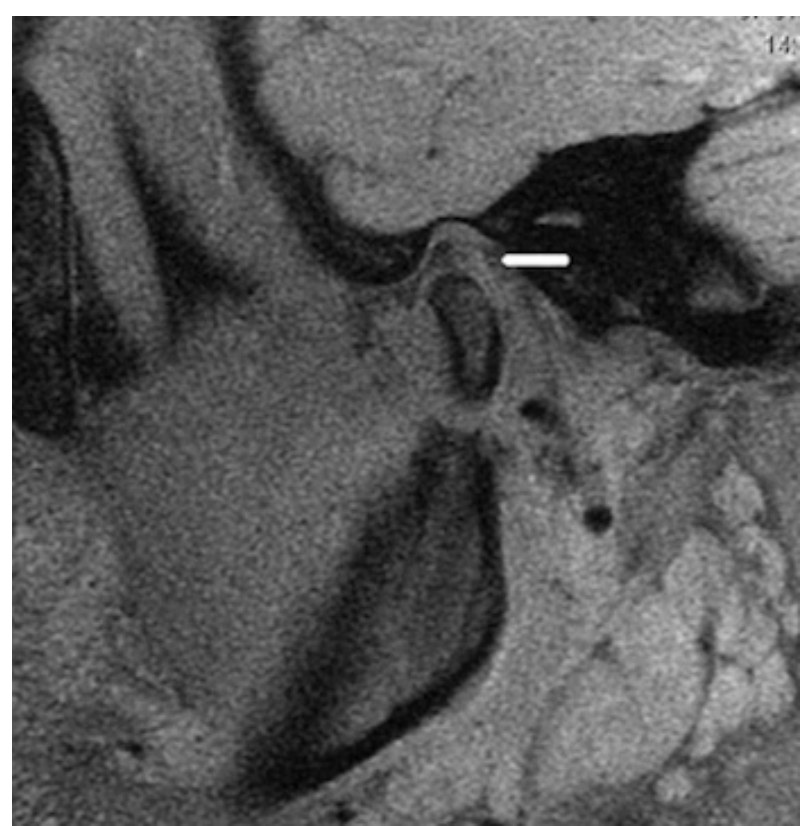

Figure 9 | MRI of a 12-year-old child with a condyle fracture showing an anteriorly displaced disc (arrow). ${ }^{6}$ 


\section{CONCLUSION}

Assessments using MRI images of the TMJs of children cause the diagnosis to be more accurate and objective. Therefore, it allows the alterations to be detected in the early stages of juvenile idiopathic arthritis. Using 3T MRI devices with contrast implies a better prognosis and treatment. In cases of condyle and ankylosis fractures, MRI seems to be satisfactory, however, the association with CT images is essential for the conclusion of the diagnosis.

\section{REFERENCES}

1. Nahás-Scocate AC, Streva AM, Lopes SLPC, Costa ALF. Ressonância magnética: recurso imagenológico na ortodontia. In: Feres M, Duarte DA, Capez M, editores. Ortodontia: estado atual da arte, diagnóstico, planejamento e tratamento. Nova Odessa: Napoleão; 2017. p. 81-8.

2. Okeson JP. Tratamento das desordens temporomandibulares e oclusão. $7^{\mathrm{a}}$ ed. Rio de Janeiro: Elsevier; 2013.

3. Pillemer FG, Masek BJ, Kaban LB. Temporomandibular joint dysfunction and facial pain in children: an approach to diagnosis and treatment. Pediatrics. 1987;80(4):565-70.

4. Moe JS, Desai NK, Aiken AH, Soares BP, Kang J, Abramowicz S. Magnetic resonance imaging of temporomandibular joints of children. J Oral Maxillofac Surg. 2016;74(9):1723-7. doi: 10.1016/j.joms.2016.03.022.

5. McQueen FM, Benton N, Perry D, Crabbe J, Robinson E, Yeoman S, et al. Bone edema scored on magnetic resonance imaging scans of the dominant carpus at presentation predicts radiographic joint damage of the hands and feet six years later in patients with rheumatoid arthritis. Arthritis Rheum 2003;48(7):1814-27. doi: 10.1002/art.11162.

6. Navallas M, Inarejos EJ, Iglesias E, Cho Lee GY, Rodriguez N, Anton J. MR imaging of the temporomandibular joint in juvenile idiopathic arthritis: technique and findings. radiographics. 2017;37(2):595-612. doi: 10.1148/rg.2017160078.

7. Dwivedi AN, Tripathi R, Gupta PK, Tripathi S, Garg S. Magnetic resonance imaging evaluation of temporomandibular joint and associated soft tissue changes following acute condylar injury. J Oral Maxillofac Surg. 2012;70(12):2829-34. doi: 10.1016/j.joms.2012.08.026.

8. Hammer MR, Kanaan Y. Imaging of the pediatric temporomandibular joint. Oral Maxillofac Surg Clin North Am. 2018;30(1):25-34. doi: 10.1016/j.coms.2017.08.008.

9. Vilanova JC, Barceló J, Puig J, Remollo S, Nicolau C, Bru C. Diagnostic imaging: magnetic resonance imaging, compu- ted tomography, and ultrasound. Semin Ultrasound CT MR. 2007;28(3):184-91. doi: 10.1053/j.sult.2007.02.003.

10. Meyers AB, Laor T. Magnetic resonance imaging of the temporomandibular joint in children with juvenile idiopathic arthritis. Pediatr Radiol. 2013;43(12):1632-41. doi: 10.1007/ soo247-013-2769-z.

11. Munir S, Patil K, Miller E, Uleryk E, Twilt M, Spiegel L, et al. Juvenile idiopathic arthritis of the axial joints: a systematic review of the diagnostic accuracy and predictive value of conventional MRI. AJR Am J Roentgenol. 2014; 202(1):199210. doi: 10.2214/AJR.12.10475.

12. Von Kalle T, Stuber T, Winkler P, Maier J, Hospach T. Early detection of temporomandibular joint arthritis in children with juvenile idiopathic arthritis: the role of contrast-enhanced MRI. Pediatr Radiol. 2015;45(3):402-10. doi: 10.1007/ soo247-014-3143-5.

13. Zwir LM, Terreri MT, Sousa SA, Fernandes AR, Guimarães AS, Hilário M. Are temporomandibular joint signs and symptoms associated with magnetic resonance imaging findings in juvenile idiopathic arthritis patients? A longitudinal study. Clin Rheumatol. 2015;34(12):2057-63. doi: 10.1007/s10067015-2925-y.

14. Hans MG, Lieberman J, Goldberg J, Rozencwieg G, Bellon E. A comparison of clinical examination, history, and magnetic resonance imaging for identifying orthodontic patients with temporomandibular joint disorders. Am J Orthod Dentofacial Orthop. 1992;101(1):54-9. doi: 10.1016/o8895406(92)70082-L.

15. Ribeiro RF, Tallents RH, Katzberg RW, Murphy WC, Moss ME, Magalhaes AC, et al. The prevalence of disc displacement in symptomatic and asymptomatic volunteers aged 6 to 25 years. J Orofac Pain. 1997;11(1):37-47.

16. Paesani D, Salas E, Martinez A, Isberg A. Prevalence of temporomandibular joint disk displacement in infants and young children. Oral Surg Oral Med Oral Pathol Oral Radiol Endod. 1999;87(1):15-9. doi: 10.1016/S1079-2104(99)70288-X.

17. Yew CC, Rahman SA, Alam MK. Temporomandibular joint ankylosis in a child: an unusual case with delayed surgical intervention. BMC Pediatr. 2015;6(15):169. doi: 10.1186/ s12887-015-0495-4.

18. Yang X, Lu C, Dong M, He D, Yang C. Evaluation of the condyle remodeling after lateral arthroplasty in growing children with temporomandibular joint ankyloses. Sci Rep. 2017;30:7(1):9922. doi: 10.1038/s41598-017-09425-5.

19. Zheng JS, Jiao ZX, Zhang SY, Yang C, Abdelrehem A, Chen MJ, et al. Correlation between the disc status in MRI and the different types of traumatic temporomandibular joint ankylosis. Dentomaxillofac Radiol. 2015;44(4):20140201. doi: 10.1259/dmfr.20140201. 